\title{
Malnutrition status, and its Associated Factors among Adult HIV Positive Attending ART at Public Hospitals of Bench Sheko Zone, South West, Ethiopia, 2020
}

Nigusie Shifera ( $\nabla$ nigusieshifera@gmail.com )

Mizan Tepi University

Abebaw Molla

Mizan Tepi University

Gebremeskel Mesafint

Mizan Tepi University

Simegnew Gichew

Mizan Tepi University

Rahel Matiyas

Mizan Tepi University

Tewodros Yosef

Mizan Tepi University

\section{Research Article}

Keywords: HIV/AIDS, Malnutrition, ART

Posted Date: February 23rd, 2021

DOl: https://doi.org/10.21203/rs.3.rs-209487/v1

License: (c) (i) This work is licensed under a Creative Commons Attribution 4.0 International License.

Read Full License 
Malnutrition status, and its Associated Factors among Adult HIV Positive Attending ART at Public Hospitals of Bench Sheko Zone, South West, Ethiopia, 2020

Nigusie Shifera ${ }^{1 *}$ (nigusieshifera@gmail.com)

Abebaw Molla ${ }^{2}$ (abebawtsehay1@ gmail.com )

Gebremeskel Mesafint ${ }^{3}$ (mulegeta111@gmail.com )

Simegnew Gichew ${ }^{4}$ (smegnewg16@gmail.com )

Rahel Matiyas ${ }^{5}$ (rahelmatiyas@gmail.com )

Tewodros Yosef ${ }^{1}$ (tewodrosyosef47@gmail.com )

\section{* Corresponding Author}

${ }^{1}$ Department of Epidemiology and Biostatics, School of Public Health, Mizan-Tepi University, Mizan-Aman, Ethiopia

${ }^{2}$ Department of Nutrition, School of Public Health, Mizan-Tepi University, MizanAman, Ethiopia

${ }^{3}$ Department of Nursing, College of Medicine and Health Sciences, Mizan-Tepi University, Mizan-Aman, Ethiopia

${ }^{4}$ Department of Nutrition, School of Public Health, Mizan-Tepi University, MizanAman, Ethiopia

${ }^{5}$ Department of Psychology, College of Social Sciences and Humanity, Mizan-Tepi University, Mizan-Aman, Ethiopia 


\section{Abstract}

Background: Almost 1.9 billion adults worldwide are overweight or obese, while 462 million are underweight. These are primarily found in countries with low and middle-incomes, like Ethiopia. Under nutrition is the frequent health problem among peoples living with HIV/AIDS, however no large-scale research, including a number of health facilities has been conducted in Ethiopia. So this study aimed to assess the nutritional status and under nutrition related factors among HIV/AIDS patients attending ART follow-up in public hospitals of Bench Sheko zones, south west, Ethiopia.

Methods: In November/2020, a cross-sectional facility study design was carried out in all public hospitals in the Bench Sheko zone. To pick the study participants, a systematic sampling technique was used. Data were collected via face-to-face interviews and entered into Epi-data 3.1, then exported to SPSS version 24 for statistical analysis. In order to identify the candidate and independent determinants of under-nutrition, bivariate and multivariable logistic regression analyses were carried out respectively. Independent determinants of under-nutrition were measured using adjusted odds ratio with their corresponding 95\% confidence level at P-value of < 0.05 cut of point.

Results: A total of four hundred two adult HIV-positive patients who were attending in ART clinics were participated with $98 \%$ response rate. The proportion of under nutrition $(\mathrm{BMI}<18.5$ $\mathrm{kg} / \mathrm{m} 2$ ), normal nutrition (BMI 18.5-24.9 kg/m2) and overweight or obese (BMI $\geq 25 \mathrm{~kg} / \mathrm{m} 2$ ) patients were 29.2\% [95\% CI: (24.6-33.5)], 61.2\% [95\% CI: (56.5-66.3)], and 9.6\% [95\% CI: (6.612.9)] respectively. Out of under nutrition patients, severe malnutrition (BMI $<16 \mathrm{~kg} / \mathrm{m} 2$ ) accounted of 5.6\%. Factors food insecurity [AOR: 3.26, 95\% CI: (1.79-5.92)], poor ART adherence [AOR: 4.22, 95\% CI: (1.47-12.14)], CD4 cell count $\leq 200$ [AOR: 5.73, 95\% CI: (2.4513.13)], and substance user [AOR: 4.11, 95\% CI: (2.31-7.30)] was independent factors of under nutrition.

Conclusion: This study found that the prevalence of malnutrition was high compared to other settings. The government should also pay due attention to improving the treatment of HIV/AIDS by offering nutritional support services in hospitals. Moreover policymaker and heath care professionals consider the effects of these factors for nutrition while providing ART service.

Key words: HIV/AIDS, Malnutrition, ART 


\section{INTRODUCTION}

Worldwide, about 38 million people were living with HIV/AIDS, over 25.5 million are in Africa. Similarly some 25.4 million people are being served while 12.6 million people are still waiting for ART treatment (1). Although 690000 AIDS-related deaths and 1.7 million new infections have been reported in 2019, of them $0.7 \%$ were adults aged 15-49 years $(1,2)$. The EDHS study in Ethiopia showed that the prevalence among adults in 2016 was almost 1 percent (3).

Malnutrition is physiological disorder that occurs because of lack of nutrients and energy to maintain the body's demand for growth, maintenance and basic functions of the body (4). Roughly 1.9 billion people are overweight or obese globally, while 462 million are underweight. These occur mainly in countries with low and medium incomes (4). Ethiopia is among the largest incidences of under nutrition in the world, with almost $49 \%$ of population lacking adequate nutrition (5).

Human nutrition and HIV/AIDS are closely linked to each other, both of which can independently cause progressive immune system damage. Malnutrition exacerbates the problem by speeding the progression of HIV infection to AIDS. HIV/AIDS is often correlated with biological and social factors that affect the ability of individuals to eat and use food (6).

There are multi-factorial causes of malnutrition in patients with HIV/AIDS. These includes food consumption disorder, medications that cause loss of appetite, nausea and vomiting, anorexia, opportunistic infections, diarrhea, nutrient mal absorption of nutrients and wasting syndrome (7). In addition, HIV has a particular impacts on nutritional status by increasing energy requirements through metabolic and oxidative changes (8). Adult patients with HIV/AIDS require 10\% more energy consumption when asymptomatic, 20-30\% more when symptomatic and increased energy intake by $30 \%$ during the recovery period compared to healthy people (8). 
Studies showed that the prevalence of malnutrition among adult HIV-positive attending ART, though different degrees. For example studies conducted in Zambia and double, revealed that the prevalence of malnutrition were $36.4 \%$ and $19.34 \%$ respectively $(9,10)$. In Ethiopia different studies have indicated different levels of malnutrition among adult HIV-positive individuals. For example a study in west Shewa pubic facility $23.6 \%$ (11), in east Harerge zone demonstrated that $30 \%$ (12), in Jimma Medical center 34\% (13), compared to 43\% \% in Jimma town Oromia region (14) of HIV positive patients had malnutrition.

In Ethiopia, studies have been conducted to investigate malnutrition among adult HIV positive individuals (11-17). However, no study has been conducted on large scale, incorporating a number of health facilities covering large demographic areas and socio-cultural diversity. Moreover the previous study does not assessed the food insecurity level of the patients. So the present study aimed to assess malnutrition status and its associated factors among adult HIV positive individuals by addressing the previous studies. 


\section{Methods and materials}

\section{Study setting, design, and period}

A Facility based cross-sectional study was conducted at Bench Sheko zone public hospitals, south west Ethiopia from November/2020. Mizan Aman town is, the administrative town of Bench Sheko zone located $585 \mathrm{~km}$ to southwest of Addis Ababa. The zone has three public hospitals, namely Chena, Tepi and Mizan Tepi university teaching hospitals, 26 health center and 128 health posts. The main food crops of Bench Sheko zone include maize, coffee, godere (taro root), and enset, while sorghum, teff, wheat and barley are cultivated to a significant extent. An average of 3540 HIV positive individuals were attending ART among the three public hospitals, of whom 1965 males and 1575 were females. The clinic provides counseling, tracing, ART treatment, nutritional and medical treatment services.

\section{Source population}

All adult people living with HIV/ADIS attending ART at public hospitals of Bench-Sheko zone.

\section{Study Population}

All adult people living with HIV/ADIS attending ART at public hospitals of Bench-Sheko zone who full fill the eligibility.

\section{Eligibility criteria}

All HIV positive aged 18 years and older, who are attending ART at public hospitals of Bench Sheko zone were included to the study. Individuals who was critical ill, having hearing impairment and severe mental illness at the time of the study were excluded.

\section{Sample size determination and sampling technique}

A single population proportion formula was used to calculate the sample size with $95 \%$ level confidence, 5\% margin of error, and considering 5\% non-response rate. A study conducted in Jimma University teaching Hospital, south west Ethiopia, the estimated prevalence of under nutrition among patients on ART (46.8\%) was used to get the maximum sample size (16), As a result, the final sample size became 402. According to the total number of ART clients in each public hospitals, proportionate number of sample was assigned for each ART clinic. Systematic sampling technique were employed to select the study participants. 
We calculated the skip interval, k=9. The first study subject was selected using lottery method, then the other study participants were selected every nine interval.

\section{Study variables}

The dependent variables were Malnutrition (under nutrition), while the independent variables were socio-demographic variables (age, sex, residence, educational status, occupation religion, ethnicity, and income), Clinical factors (HIV related) factors (Diarrhea, ART status, Duration of ART, CD4 count, Viral Load, WHO staging, TB treatment, ART adherence, Hemoglobin level), Behavioral factor (Alcohol use, Substance use, and extra sexual partner) and Vulnerability characteristics(Household Food consumption, Food aid) were the independent variables.

\section{Measurements and operational definitions}

Under weight (Under Nutrition): The person who has Body mass index (BMI) less than $18.49 \mathrm{Kg} / \mathrm{M}^{2}(18)$.

Normal weight: The person who has Body mass index (BMI) between less than $18.5 \mathrm{Kg} / \mathrm{M}$ to 24.9 $\mathrm{Kg} / \mathrm{M}^{2}(18)$.

Over weight (over nutrition): The person who has Body mass index (BMI) greater than $25 \mathrm{Kg} / \mathrm{M}$ $2(18)$

Obese (over Nutrition): The person who has Body mass index (BMI) greater than $30 \mathrm{Kg} / \mathrm{M}^{2}(18)$. Adherent Patients: Those who score greater than or equal to 4 based on Morisky Medication Adherence Scale-8 (MMAS-8) (19).

Non adherent Patients: are those who score less than 4 based on Morisky Medication Adherence Scale-8 (MMAS-8) (19).

Food secure household: if household head responds no to all questions items 1-9 or responds yes to question item 1 and experience rarely in the past four weeks (20).

Food insecure household: if household heads responds at least yes to question item 1 and experience sometimes in the past four weeks (20).

Current Substance use: Using at least one of a specific substance (Alcohol, Khat, Cigarette and Others) for nonmedical purpose within last 3 months according to Alcohol, smoking and substance involvement screening tool (ASSIST) (21).

Ever Substance use: using at least one of any specific substance (Alcohol, Khat, Cigarette and Others) for the nonmedical purpose at least once in a lifetime according to ASSIST (21). 


\section{Data collection procedures and tools}

Data were collected using pretested and structured interviewer administered questionnaire, checklist, and measurements. Three nurses and one public health professionals were recruited as data collectors and supervisor respectively. The questionnaires included socio-demographics, clinical factors, household and behavioral characteristics.

Weight and height measurement of the participants were done according to FANTA guidelines (22). Household food security status was assessed using the Household Food Insecurity Access Scale (HFIAS) (20), which was established and validated by Food and Nutrition Technical Assistance (FANTA). Drug adherence of the patient was assessed using eight-item Morisky Medication Adherence Scale (MMAS-8) (19). ASSIST which is a brief screening questionnaire developed by the WHO to find out about people's use of psychoactive substances was used to assess current and ever substance use history of the participants (21). The study was conducted following the World Medical Association declaration of Helsinki ethical principles for medical research involving human subjects (23).

\section{Data quality assurance}

Data collection tool was initially prepared in English translated to local language Amharic and back-translated into English to check its consistency. A pretest was done among 5\% of study sample size and training was provided to the data collectors and supervisors on the objective of the study, maintenance of ethical standards, and methods of data collection. A supervisor checked the completeness of the collected data daily and overall data collection was monitored by investigators. Also data completeness were checked before enter into Epi-data 3.1. Data coding and cleaning was performed by cross-checking to printout data for possible errors. Moreover, missing values and outliers were checked before by running descriptive analysis. 


\section{Data Processing and analysis}

Data were cleaned and entered into Epi data 3.1 and then exported to SPSS version 24 for statically analysis. The descriptive statistics were presented in frequency, tables and graphs. Normality assumption was checked for continuous variables. Body mass index (BMI) was calculated by dividing the weight in $\mathrm{kg}$ by square of height in meter. Under-nutrition was categorized as BMI below $18.5 \mathrm{Kg} / \mathrm{m} 2(15)$.

The association between under nutrition with each covariate was assessed using bivariate logistic regression to identify a candidate variable for multivariate logistic regression. Variables with $\mathrm{P}$ value $<0.25$ were taken into multiple logistic regression analysis to identify independent predictors of under-nutrition.

A backward likelihood ratio with a 0.1 probability of removal was used to build the model. To check the goodness of fit of the final model, the Hosmer Lemshow test of goodness of fit considering good fit at P-value $>0.05$ was used. Finally, independent predictors of under-nutrition were declared at $\mathrm{P}$-value $<0.05$ cut-off point and strength of the association was assessed using AORs with their corresponding at $95 \%$ confidence level. 


\section{RESULTS}

\section{Socio-demographic Characteristics}

A total of three hundred nighty four adult HIV-positive patients who were enrolled in ART clinics were participated with $100 \%$ response rate. The mean BMI (SD) and age of the participants were 19.9(2.9), 34(11) respectively. The majority of the participants 181 (45.9\%) were in the age group 25 to 34 range. More than half of 216(54.8\%) and about 237(60.2\%) were female in sex and urban in residence. Nearly Similar proportion 157(39.8\%) and 156(39.6\%) were Orthodox in religion and Bench in ethnicity. Concerning to marital status about 248(62.9\%) were married and about $145(36.8 \%)$ of the participants were completed their secondary education (see table 1).

Table 1: Socio-demographic characteristics of patients grouped by nutritional status (BMI) in Bench Sheko public hospital, Southwest Ethiopia, 2020.

\begin{tabular}{|l|l|l|l|l|}
\hline Variables & $\begin{array}{l}\text { Under nutrition } \\
\text { No } \%)\end{array}$ & $\begin{array}{l}\text { Normal weight } \\
\text { No } \%)\end{array}$ & $\begin{array}{l}\text { Overweight } \\
\text { or above } \\
\text { No (\%) }\end{array}$ & $\begin{array}{l}\text { Total } \\
\text { No (\%) }\end{array}$ \\
\hline Age & & & & \\
\hline $18-24$ & $21(23.5)$ & $30(12.4)$ & $8(21.1)$ & $65(16.5)$ \\
\hline $25-34$ & $49(42.6)$ & $116(48.1)$ & $16(42.1)$ & $181(45.9)$ \\
\hline $35-44$ & $19(16.5)$ & $50(20.7)$ & $6(15.8)$ & $75(19)$ \\
\hline$\geq 45$ & $20(17.4)$ & $45(18.7)$ & $8(21.1)$ & $73(18.5)$ \\
\hline Sex & & & & \\
\hline Male & $49(42.6)$ & $113(46.9)$ & $16(42.1)$ & $178(45.2)$ \\
\hline Female & $66(57.4)$ & $128(53.1)$ & $22(57.9)$ & $216(54.8)$ \\
\hline Residence & & & & $237(60.2)$ \\
\hline Urban & $64(55.7)$ & $146(60.6)$ & $27(71.1)$ & $157(39.8)$ \\
\hline Rural & $51(44.3)$ & $95(39.4)$ & $11(28.9)$ & \\
\hline Religion & & & & $157(39.8)$ \\
\hline Orthodox & $50(43.5)$ & $89(36.9)$ & $18(47.4)$ & $106(26.9)$ \\
\hline Muslim & $21(18.3)$ & $75(31.1)$ & $10(26.3)$ & $131(33.2)$ \\
\hline Protestant & $44(38.3)$ & $77(32)$ & $10(26.3)$ & \\
\hline Ethnicity & & & & $156(39.6)$ \\
\hline Bench & $48(41.7)$ & $93(38.6)$ & $15(39.5)$ & $104(26.4)$ \\
\hline Kaffa & $19(16.5)$ & $79(32.8)$ & $6(15.8)$ & $77(19.5)$ \\
\hline Amhara & $31(27)$ & $36(14.9)$ & $10(26.3)$ & \\
\hline Oromo & $17(14.8)$ & $33(13.7)$ & $7(18.4)$ & $57(14.5)$ \\
\hline
\end{tabular}




\begin{tabular}{|l|l|l|l|l|}
\hline Marital status & & & & \\
\hline Single & $13(11.3)$ & $31(12.9)$ & $10(26.3)$ & $54(13.7)$ \\
\hline Married & $74(64.3)$ & $153(63.5)$ & $21(55.3)$ & $248(62.9)$ \\
\hline Widowed & $15(13)$ & $35(14.5)$ & $6(15.8)$ & $56(14.2)$ \\
\hline Divorced & $13(11.3)$ & $22(9.1)$ & $1(2.6)$ & $36(9.1)$ \\
\hline Educational level & & & & \\
\hline Uneducated & $25(21.7)$ & $20(8.3)$ & $0(0.0)$ & $45(11.4)$ \\
\hline Primary & $45(39.1)$ & $84(34.9)$ & $18(47.4)$ & $147(37.3)$ \\
\hline Secondary & $33(28.7)$ & $101(41.9$ & $11(28.9)$ & $145(36.8)$ \\
\hline Tertiary & $12(10.4)$ & $36(14.9)$ & $9(23.7)$ & $57(14.5)$ \\
\hline Occupation & & & & \\
\hline Unemployed & $25(21.7)$ & $38(15.8)$ & $6(15.8)$ & $69(17.5)$ \\
\hline House wife & $13(11.3)$ & $26(10.8)$ & $3(7.9)$ & $42(10.7)$ \\
\hline Daily labor & $16(13.9)$ & $23(9.5)$ & $5(13.2)$ & $44(11.2)$ \\
\hline Merchant & $37(32.2)$ & $100(41.5)$ & $14(36.8)$ & $151(38.3)$ \\
\hline Government employee & $24(20.9)$ & $54(22.4)$ & $10(26.3)$ & $88(22.3)$ \\
\hline Average Monthly Income & & & & \\
\hline$\leq 2500 E T B$ & $70(60.9)$ & $104(43.2)$ & $16(42.1)$ & $190(48.2)$ \\
\hline$>2500 E T B$ & $45(39.1)$ & $137(56.8)$ & $22(57.9)$ & $204(51.8)$ \\
\hline
\end{tabular}

\section{Clinical and Behavioral related characteristics}

This study also revealed the clinical and behavioral characteristics of the study participants. Most of the participants $231(58.6 \%)$ were diagnosed for HIV $\geq 2$ years and about $165(41.9 \%)$ had more than one year ART duration. Lightly above three-fourth 303(76.9\%) had good ART adherence and about 261(66.2\%) had hemoglobin level of $\geq 12 \mathrm{mg} / \mathrm{dl}$. More over nearly half $191(48.5 \%)$ of the participants had CD4 level between 200 to 500 cells/mm3 and about 274(69.5\%) of the participants had got food aid. Concerning to the behavioral characteristics nearly one-fourth 106(26.9\%) were currently substance user and about 167(42.4\%) had history of extramarital sex (table 2).

Table 2: Clinical and lifestyle-related characteristics and nutritional status of adults receiving ART at Bench Sheko zone public hospitals, southwest Ethiopia, 2020

\begin{tabular}{|l|l|l|l|l|}
\hline Variables & $\begin{array}{l}\text { Under-nutrition } \\
\text { No }(\%)\end{array}$ & $\begin{array}{l}\text { Normal weight } \\
\text { No }(\%)\end{array}$ & $\begin{array}{l}\text { Overweight or } \\
\text { above No }(\%)\end{array}$ & $\begin{array}{l}\text { Total } \\
\text { No }(\%)\end{array}$ \\
\hline
\end{tabular}




\begin{tabular}{|c|c|c|c|c|}
\hline HIV diagnosi & & & & \\
\hline$\leq 2$ yeras & $47(40.9)$ & 94(39) & $22(57.9)$ & 163(41.4) \\
\hline$>2$ year & $68(59.1)$ & 147(61) & $16(42.1)$ & $231(58.6)$ \\
\hline ART duration & & & & \\
\hline$<6$ month & $31(27)$ & $54(22.4)$ & $9(23.7)$ & $94(23.9)$ \\
\hline 6-12 months & $34(29.6)$ & $87(36.1$ & $14(36.8)$ & $135(34.3)$ \\
\hline$>12$ months & $50(43.5)$ & $100(41.5)$ & $15(39.5)$ & $165(41.9)$ \\
\hline CD4 Count & & & & \\
\hline$\leq 200$ & $35(30.4)$ & 19(7.9) & $4(10.5)$ & $58(14.7)$ \\
\hline $200-500$ & $46(40)$ & $126(52.3)$ & $19(50)$ & 191(48.5) \\
\hline$\geq 500$ & $34(29.6)$ & $96(39.8)$ & $15(39.5)$ & $145(36.8)$ \\
\hline WHO staging & & & & \\
\hline Stage I & 11(9.6) & $37(15.4)$ & $5(13.2)$ & $53(13.5)$ \\
\hline Stage II & $72(62.6)$ & $175(72.6)$ & $29(76.3)$ & $276(70.1)$ \\
\hline Stage III & $22(19.1)$ & $20(8.3)$ & $2(5.3)$ & $44(11.2)$ \\
\hline Stage IV & $10(8.7)$ & $9(3.7)$ & $2(5.3)$ & $21(5.3)$ \\
\hline ART adheren & & & & \\
\hline Poor & $12(10.4)$ & $9(3.7)$ & $0(0)$ & $21(5.3)$ \\
\hline Fair & $20(17.4)$ & $42(17.4)$ & $8(21.1)$ & $70(17.8)$ \\
\hline Good & $83(72.2)$ & $190(78.8)$ & $30(78.9)$ & $303(76.9)$ \\
\hline Hemoglobin 1 & & & & \\
\hline$\leq 12 \mathrm{mg} / \mathrm{dl}$ & $53(46.1)$ & $76(31.5)$ & $4(10.5)$ & $133(33.8)$ \\
\hline$>12 \mathrm{mg} / \mathrm{dl}$ & $62(53.8)$ & $165(68.5)$ & $34(89.5)$ & $261(66.2)$ \\
\hline Diarrhea & & & & \\
\hline Yes & $55(47.8)$ & $52(21.6)$ & $11(28.9)$ & $118(29.9)$ \\
\hline No & $60(52.2)$ & 189(78.4) & $27(71.1)$ & $276(70.1)$ \\
\hline TB & & & & \\
\hline Yes & $31(27)$ & $34(14.1)$ & $4(10.5)$ & $69(17.5)$ \\
\hline No & $84(73)$ & $207(85.9)$ & $34(89.5)$ & $325(82.5)$ \\
\hline Hospital adm & & & & \\
\hline
\end{tabular}




\begin{tabular}{|c|c|c|c|c|}
\hline Yes & $80(69.6)$ & $128(53.1)$ & $24(63.2)$ & $232(58.9)$ \\
\hline No & $35(30.4)$ & $113(46.9)$ & $14(36.8)$ & $162(41.1)$ \\
\hline \multicolumn{5}{|c|}{ HIV disclosure } \\
\hline Yes & $93(80.9)$ & $186(77.2)$ & $36(94.7)$ & $315(79.9)$ \\
\hline No & $22(19.1)$ & $55(22.8)$ & $2(5.3)$ & $79(20.10$ \\
\hline \multicolumn{5}{|c|}{ Nutritional counseling's } \\
\hline Yes & $75(65.2)$ & $143(59.3)$ & $23(60.5)$ & $241(61.2)$ \\
\hline No & $40(34.8)$ & $98(40.7)$ & $15(39.5)$ & $153(38.8)$ \\
\hline \multicolumn{5}{|c|}{ Functional status } \\
\hline Bed ridden & 11(9.6) & $16(6.6)$ & $4(10.5)$ & $31(7.9)$ \\
\hline Ambulatory & $10(8.7)$ & $14(5.8)$ & $0(0.0)$ & $24(6.1)$ \\
\hline Working & $94(81.7)$ & 211(87.6) & $34(89.5)$ & $339(86)$ \\
\hline \multicolumn{5}{|c|}{ Opportunistic Infection } \\
\hline Yes & $37(32.2)$ & $37(15.4)$ & $5(13.2)$ & $79(20.1)$ \\
\hline No & $78(67.8)$ & $204(84.6)$ & $33(86.8)$ & $315(79.9)$ \\
\hline \multicolumn{5}{|c|}{ Difficulty of swallowing } \\
\hline Yes & $15(13)$ & $24(10)$ & $1(2.6)$ & $40(10.2)$ \\
\hline No & $100(87)$ & $217(90)$ & $37(97.4)$ & $354(89.8)$ \\
\hline \multicolumn{5}{|c|}{ Comorbidity } \\
\hline Yes & $37((32.2)$ & $46(19.1)$ & $7(18.4)$ & $90(22.8)$ \\
\hline No & $78(67.8)$ & 195(80.9) & $31(81.6)$ & $304(77.2)$ \\
\hline \multicolumn{5}{|l|}{ Food aid } \\
\hline Yes & $35(30.4)$ & $71(29.5)$ & $14(36.8)$ & $120(30.5)$ \\
\hline No & $80(69.6)$ & $170(70.5)$ & $24(63.2)$ & $274(69.5)$ \\
\hline \multicolumn{5}{|c|}{ Food insecurity } \\
\hline Yes & $25(21.7)$ & $127(52.7)$ & $19(50)$ & $171(43.4)$ \\
\hline No & $90(78.3)$ & $114(47.3)$ & $19(50)$ & $223(56.6)$ \\
\hline \multicolumn{5}{|c|}{ Current substance use } \\
\hline Yes & $53(46.1)$ & $43(17.8)$ & $10(26.3)$ & $106(26.9)$ \\
\hline No & $62(53.9)$ & 198(82.2) & $28(73.7)$ & $288(73.1)$ \\
\hline
\end{tabular}




\begin{tabular}{|l|l|l|l|l|}
\hline Ever substance use & & & & \\
\hline Yes & $22(19.1)$ & $64(26.6)$ & $11(28.9)$ & $97(24.6)$ \\
\hline No & $93(80.9)$ & $177(73.4)$ & $27(71.1)$ & $297(75.4)$ \\
\hline Extra marital sex & & & & \\
\hline Yes & $44(38.3)$ & $108(44.8)$ & $15(39.5)$ & $167(42.4)$ \\
\hline No & $71(61.7)$ & $133(55.2)$ & $23(60.5)$ & $227(57.6)$ \\
\hline
\end{tabular}

\section{Prevalence of Malnutrition}

The proportion of under nutrition (BMI $<18.5 \mathrm{~kg} / \mathrm{m} 2$ ), normal nutrition (BMI 18.5-24.9 kg/m2) and overweight or obese (BMI $\geq 25 \mathrm{~kg} / \mathrm{m} 2)$ patients were $29.2 \%$ [95\% CI :( 24.6-33.5)], 61.2\% [95\% CI: (56.5-66.3)], and 9.6\% [95\% CI: (6.6-12.9)] respectively. Out of under nutrition patients, severe malnutrition (BMI $<16 \mathrm{~kg} / \mathrm{m} 2$ ) accounted of $5.6 \%$ (Figure 1).

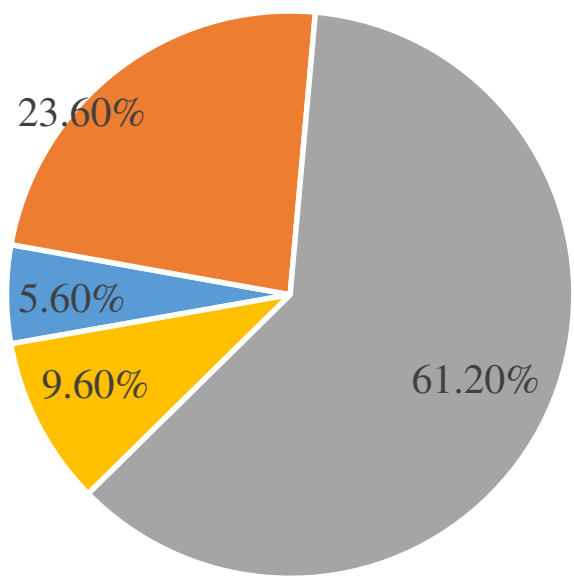

- Sever malnutrition $\quad$ - Moderate malnutrition $\quad$ Normal $\quad$ Over weight or obese

Figure 1: Nutritional status of HIV/AIDS patients on follow-up care in Bench Sheko zone public hospitals, Southwest Ethiopia, 2020 


\section{Predictors of under-nutrition}

From the total 12 candidate variables entered into multivariable analysis, four variables were found to be independently associated with under nutrition among Adult HIV positive individuals attending ART. Under nutrition was about three times [AOR: 3.26, 95\% CI: (1.79-5.92)] more likely among patients who had food insecurity than who had not.

The odds of under nutrition were four times [AOR: 4.22, 95\% CI: (1.47-12.14)], higher among HIV patients who had poor ART adherence. HIV/AIDS patients with CD4 cell count $\leq 200$ cells/mm3 were nearly six times [AOR: 5.73, 95\% CI: (2.45-13.13)], more likely under nourished than patients with CD4 cell count $\geq 500$ cells $/ \mathrm{mm} 3$. Moreover individuals who were substance user is about four times [AOR: 4.11, 95\% CI: (2.31-7.30)], higher risks of developing under nutrition as compared to who did not use (see table 3 ).

Table 3: Multivariate association of different variables with under nutrition among HIV/AIDS patients on follow-up care in Bench Sheko zone public hospitals, Southwest Ethiopia, 2020.

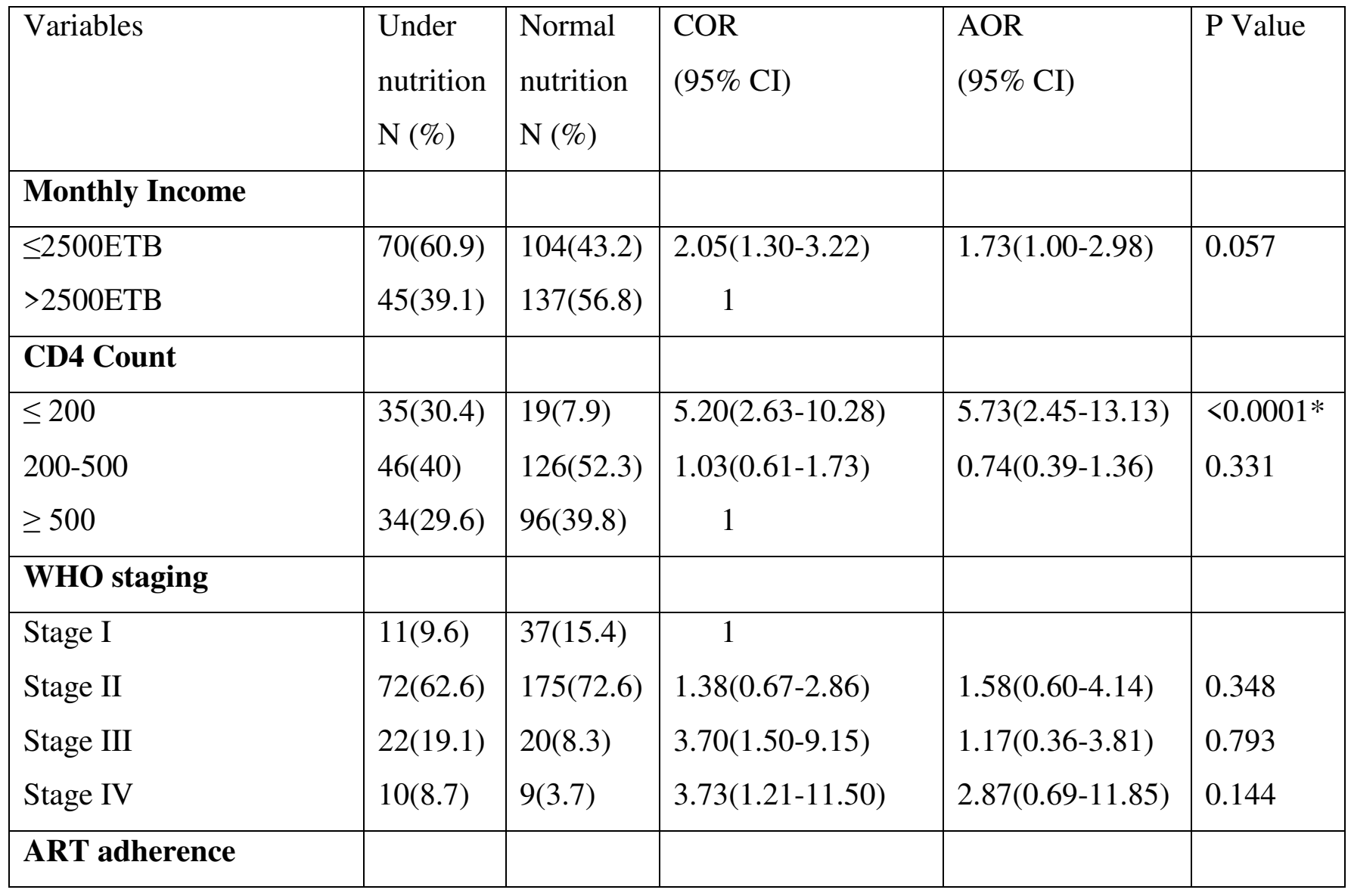




\begin{tabular}{|c|c|c|c|c|c|}
\hline $\begin{array}{l}\text { Poor } \\
\text { Fair } \\
\text { Good }\end{array}$ & $\begin{array}{l}12(10.4) \\
20(17.4) \\
83(72.2)\end{array}$ & $\begin{array}{l}9(3.7) \\
42(17.4) \\
190(78.8)\end{array}$ & $\begin{array}{l}3.05(1.24-7.52) \\
1.09(0.60-1.97) \\
1\end{array}$ & $\begin{array}{l}4.22(1.47-12.14) \\
0.81(0.377-1.74)\end{array}$ & $\begin{array}{l}0.007 * \\
0.588\end{array}$ \\
\hline \multicolumn{6}{|c|}{ Hemoglobin level } \\
\hline $\begin{array}{l}\leq 12 \mathrm{mg} / \mathrm{dl} \\
>12 \mathrm{mg} / \mathrm{dl}\end{array}$ & $\begin{array}{l}53(46.1) \\
62(53.8)\end{array}$ & $\begin{array}{l}76(31.5) \\
165(68.5)\end{array}$ & $\begin{array}{c}1.85(1.17-2.93) \\
1\end{array}$ & $1.75(0.95-3.20)$ & 0.71 \\
\hline \multicolumn{6}{|c|}{ Food insecurity } \\
\hline $\begin{array}{l}\text { Yes } \\
\text { No }\end{array}$ & $\begin{array}{l}25(21.7) \\
90(78.3)\end{array}$ & $\begin{array}{l}127(52.7) \\
114(47.3)\end{array}$ & $\begin{array}{l}4.01(2.41-6.68) \\
1\end{array}$ & $3.26(1.79-5.92)$ & $<0.0001^{*}$ \\
\hline \multicolumn{6}{|l|}{ Diarrhea } \\
\hline $\begin{array}{l}\text { Yes } \\
\text { No }\end{array}$ & $\begin{array}{l}55(47.8) \\
60(52.2)\end{array}$ & $\begin{array}{l}52(21.6) \\
189(78.4)\end{array}$ & $\begin{array}{l}3.33(2.07-5.37) \\
1\end{array}$ & $1.39(0.73-2.65)$ & 0.318 \\
\hline \multicolumn{6}{|l|}{ TB } \\
\hline $\begin{array}{l}\text { Yes } \\
\text { No }\end{array}$ & $\begin{array}{l}31(27) \\
84(73)\end{array}$ & $\begin{array}{l}34(14.1) \\
207(85.9)\end{array}$ & $\begin{array}{l}2.25(1.30-3.89) \\
1\end{array}$ & $1.35(0.61-2.99)$ & 0.457 \\
\hline \multicolumn{6}{|c|}{ Hospital admission } \\
\hline $\begin{array}{l}\text { Yes } \\
\text { No }\end{array}$ & $\begin{array}{l}80(69.6) \\
35(30.4)\end{array}$ & $\begin{array}{l}128(53.1) \\
113(46.9)\end{array}$ & $\begin{array}{c}2.02(1.26-3.23) \\
1\end{array}$ & $1.49(0.85-2.62)$ & 0.160 \\
\hline \multicolumn{6}{|c|}{ Opportunistic Infection } \\
\hline $\begin{array}{l}\text { Yes } \\
\text { No }\end{array}$ & $\begin{array}{l}37(32.2) \\
78(67.8)\end{array}$ & $\begin{array}{l}37(15.4) \\
204(84.6)\end{array}$ & $\begin{array}{l}\text { 2.61(1.55-4.42) } \\
1\end{array}$ & $1.00(0.44-2.25)$ & 0.999 \\
\hline \multicolumn{6}{|c|}{ Comorbidity } \\
\hline $\begin{array}{l}\text { Yes } \\
\text { No }\end{array}$ & $\begin{array}{l}37(32.2) \\
78(67.8)\end{array}$ & $\begin{array}{l}46(19.1) \\
195(80.9)\end{array}$ & $\begin{array}{l}2.01(1.21-3.33) \\
1\end{array}$ & $0.70(0.29-1.70)$ & 0.435 \\
\hline \multicolumn{6}{|c|}{ substance use } \\
\hline $\begin{array}{l}\text { Yes } \\
\text { No }\end{array}$ & $\begin{array}{l}53(46.1) \\
62(53.9)\end{array}$ & $\begin{array}{l}43(17.8) \\
198(82.2)\end{array}$ & $\begin{array}{l}3.93(2.40-6.44) \\
1\end{array}$ & $4.11(2.31-7.30$ & $<0.0001^{*}$ \\
\hline
\end{tabular}

Key $*=\mathrm{P}$ value $<0.05,1=$ reference category 


\section{Discussion}

This study showed that the prevalence of under nutrition and overweight or Obesity were 29.2\% and $9.6 \%$, respectively. Among under nutrition, severe malnutrition (BMI $<16 \mathrm{~kg} / \mathrm{m} 2)$ accounted of $9 \%$. In addition, this study also indicated that food insecurity, CD4 count, ART adherence and current substance user were the independent factors associated with under nutrition.

According to this study the prevalence of under-nutrition was close to that of a study conducted in various parts of Ethiopia; 30\% in hospitals in the east Harerge zone (12), 25.2\% in Butajira hospital (24), and 27\% in Nekemte referral hospital (25), However the prevalence of this study was lower than $60.2 \%$, west Gojam zone public hospitals (17), 46.8\% in Jimma University specialized hospital (16) $43 \%$ in south west Oromia region (14), and higher than study conducted in $12.3 \%$ in Dilla university hospital (26) $18.2 \%$ in Arba Minch area public health facilities (15). Similarly, the prevalence is also much higher compared to studies done in different parts of the world; $19.5 \%$ in Tanzania (27), 10\% in Zimbabwe (9), and 19.2\% in Senegal (28). The potential difference in the prevalence of malnutrition could be attributable to socio-economic, food and cultural factors.

This study revealed that food insecurity has been found to be significantly associated with undernutrition. HIV patients who had food insecurity were 3.3 times more likely under-nourished when compared to counterparts. Similarly, the research done in East Hararge Zone hospitals of Ethiopia and Senegal found that patients with household food deficiency had higher risks undernourishment $(12,28)$. This is because there is insufficient food to satisfy nutritional requirements for productive and healthy living, contributing to macro and micronutrient deficiencies.

There was a strong correlation between CD4 numbers and under-nutrition with respect to CD4 counts. Patients with a CD4 count of $<200$ cells $/ \mathrm{mm} 3$ were approximately six times more likely than those with a CD4 count of $>500$ cells $/ \mathrm{mm} 3$ to grow under-nutrition. Similarly, the Jimma Ethopia, Senegal, Tanzania, study found that CD4 was significantly associated with lower CD4 counts $(13,27,28)$. On the other hand, the results of research conducted in the southern part of Ethiopia at Dilla University Hospital indicate that CD4 has no major impact on nutrition (26). Contrary to our research results, the disparity could be due to differences in the cultural variation of the study population and the study duration (12). 
This study also revealed that drug adherence had significant association with under nutrition. HIV patients who had poor ART adherence were nearly four times higher risks of developing under nutrition when compared to counterparts. Study done in Senegal and Ethiopia revealed patients who had good drug adherence had less likely to develop under nutrition $(25,28,29)$. This may be due to reducing the dietary intake and nutrient absorption.

Current substance use has significant effect on under nutrition. Patients who use any substance in the last three months were four times more likely develop under nutrition as compared to those who had not use. Study done in Arbamnch and Canada showed that Current tobacco-smoking adults enrolled in ART programs were at higher risk of being undernourished $(15,30)$. However, study in Nepal showed behavioral factors like alcohol and smoking were found to have no association with under nutrition (31). The possible difference may be due to difference in study population, study design and period.

\section{Conclusion and Recommendation}

This study revealed that the prevalence of malnutrition was high compared to other settings in Ethiopia. It was also shown that food insecurity, poor ART adherence, CD4 cell count $\leq 200$ cells/mm3, substance use were independently associated with under nutrition among adult HIV/AIDS patients attending ART.

This demands the government to give due attention to strengthening the HIV/AIDS treatment, nutritional assessment, supplementation, counseling, care and support to patients and support services at hospitals. In addition, the implications of food insecurity, poor ART adherence, CD4 cell count less than 200 cells/mm3 and substance use should be considered by policy makers and health professionals working at the ART clinic on the nutritional status among adult HIV patients.

\section{Limitation of the study}

The cross-sectional nature of the data, which makes it difficult to draw conclusions about the direction of relations among study variables. 


\section{List of abbreviations}

AOR: Adjusted Odds Ratio; ART: Anti-Retroviral Therapy; BMI: Body Mass Index; CI: Confidence Interval; COR: Crude Odds Ratio; EDHS: Ethiopian Demographic and Health Survey; FANTA: Food and Nutrition Technical Assistance; HFIAS: Household Food Insecurity Access Scale; HIV: Human Immune Deficiency Virus; MMAS-8: Morisky Medication Adherence Scale-8; MTU: Mizan Tepi University; SD: Standard Deviation; SPSS: Statistical Package for the Social Sciences; WHO: World Health Organization

\section{Declarations}

\section{Ethics approval and consent to participate}

The research was approved and ethical clearance was obtained from institutional review board (IRB) of Mizan Tepi University. Approval letters was taken from each hospital medical director. The objective and purpose of the study was verified briefly to the study participant, confidentiality was assured, and informed written consent was obtained from each participants. For uneducated participants, informed consent was obtained from legally authorized representatives.

\section{Funding}

The study was not funded by any organizations.

\section{Availability of data and materials}

The datasets created and analyzed during the study will be made available to organizations and individuals by the first author based on fair request.

\section{Authors' Contribution}

NS, AM, GM, SG, RM, and TW wrote the protocol, participated in data collection, analyzed the data and wrote the manuscript. All authors read and approved the final manuscript.

\section{Consent for publication}

Not applicable

\section{Competing interests}

The authors declare that they have no competing interests. 


\section{Acknowledgments}

Our heartfelt thank goes to Mizan Tepi University for financial support. Our thanks also goes to Bench-Sheko Zone hospitals staffs for the provision of necessary information to the study area. Moreover, we would like to thank study participants who voluntarily participated in this study. Finally, we also acknowledge authors of an article available at: https://www.hindawi.com/journals/jnme/2020/6986830/ for used at method description. 


\section{References}

1. UNAIDS. UNAIDS. Joint United Nations Programme on HIV/AIDS. UNAIDS data 2020. Geneva, Switzerland. [Internet]. 2020. Available from: https://www.unaids.org/sites/default/files/media_asset/2020_aids-data-book_en.pdf

2. WHO Global HIV, Hepatitis and STIs Programmes [Internet]. 2020. Available from: https://www.who.int/gho/hiv/epidemic_status/prevalence/en/

3. Demographic health Survey H. Ethiopia [Internet]. Addis Abeba; 2016. Available from: https://dhsprogram.com/pubs/pdf/FR328/FR328.pdf

4. WHO. Malnutrition [Internet]. 2020. Available from: https://www.who.int/news-room/factsheets/detail/malnutrition

5. Comprehensive Africa Agriculture Development Programme. East and Central Africa Regional CAADP Nutrition Program Development Workshop Nutrition Country Paper Ethiopia. 2013;(March):1-17. Available from: http://www.fao.org/fileadmin/user_upload/wa_workshop/ECAfricacaadp/Ethiopia_NCP_190213.pdf

6. Duggal S, Chugh T Das, Duggal AK. HIV and malnutrition: Effects on immune system. Clin Dev Immunol [Internet]. 2012;2012. Available from: https://www.hindawi.com/journals/jir/2012/784740/

7. Hecker LM, Kotler DP. Malnutrition in Patients with AIDS. Nutr Rev [Internet]. 1990;48(11):393-401. Available from: https://doi.org/10.1111/j.17534887.1990.tb02888.x

8. WHO. Nutrient requirements for people living with HIV / AIDS [Internet]. Vol. Geneva, Sw, World Health Organization. 2003. Available from: http://motherchildnutrition.org/nutrition-hiv-aids/nutrition-living-with-hiv-aids/index.html

9. Takarinda KC, Mutasa-apollo T, Madzima B, Nkomo B, Chigumira A, Banda M, et al. Malnutrition status and associated factors among HIV-positive patients enrolled in ART clinics in Zimbabwe. 2017;1-11. Available from: https://www.researchgate.net/publication/313418133_Malnutrition_status_and_associated _factors_among_HIV-positive_patients_enrolled_in_ART_clinics_in_Zimbabwe

10. Luma HN, Albert S, Bagnaka F, Mboligong FN, Temfack E, Donfack OT, et al. Malnutrition in patients admitted to the medical wards of the Douala General Hospital : a cross - sectional study. BMC Res Notes [Internet]. 2017;1-6. Available from: https://bmcresnotes.biomedcentral.com/articles/10.1186/s13104-017-2592-y 
11. Delelegn Y. G, K.T. H, E.M. K, R.T. Z. Food insecurity, nutritional status, and factors associated with malnutrition among people living with HIV/AIDS attending antiretroviral therapy at public health facilities in West Shewa Zone, Central Ethiopia. Biomed Res Int [Internet]. 2018;2018:1-10. Available from: http://www.embase.com/search/results?subaction=viewrecord\&from=export\&id=L62227 9277\%0Ahttp://dx.doi.org/10.1155/2018/1913534

12. Dedha.etal. Undernutrition and associated factors among adults human immunodeficiency virus positive on antiretroviral therapy in hospitals, East Hararge Zone, Oromia, Ethiopia: A cross-sectional study. Int J Health Sci (Qassim) [Internet]. 2017;11(5):35-42. Available from:

http://www.ncbi.nlm.nih.gov/pubmed/29114193\%0Ahttp://www.pubmedcentral.nih.gov/a rticlerender.fcgi?artid=PMC5669510

13. Daka DW, Ergiba MS. Prevalence of malnutrition and associated factors among adult patients on antiretroviral therapy follow-up care in Jimma Medical. 2020;3:1-15. Available from: http://dx.doi.org/10.1371/journal.pone.0229883

14. AB G, AE G, DB K. Malnutrition and Associated Factors among Adult People Living with HIV/AIDS Receiving Antiretroviral Therapy at Organization for Social Service Health Development in Jimma Town Oromia Region South West Ethiopia. Gen Med Open Access. 2018;06(02):4-11.

15. Zemede Z, Tariku B, Kote M, Estifanos W. Undernutrition and associated factors among HIV-positive adult patients enrolled in antiretroviral therapy (ART) clinics in the arba minch area, southern Ethiopia. HIV/AIDS - Res Palliat Care [Internet]. 2019;11:147-54. Available from: https://www.hindawi.com/journals/jnme/2020/6986830/

16. Habtamu M, Mulu H, Hamza L, Alemseged F. Prevalence of Malnutrition and Associated Factors among Hospitalized Patients with Acquired Immunodeficiency Syndrome in Jimma University Specialized Hospital , Ethiopia. 2014; Available from: https://www.ajol.info/index.php/ejhs/article/view/135634

17. Sewale E. Magnitude of malnutrition and associated factors among HIV infected children attending HIV-care in three public hospitals in East and West Gojjam Zones, Amhara, Northwest, Ethiopia, 2017: A cross-sectional study. BMC Res Notes [Internet]. 2018;11(1):1-6. Available from: https://doi.org/10.1186/s13104-018-3882-8

18. CDC. Healthy Weight About Adult BMI What are the BMI trends for adults in the United States? $\quad$ [Internet]. 2020. Available from: https://www.cdc.gov/healthyweight/assessing/bmi/adult_bmi/index.html

19. Cuevas C De, Pe W. Psychometric properties of the eight-item Morisky Medication 
Adherence Scale ( MMAS-8) in a psychiatric nate. 2015; Available from: https://www.ncbi.nlm.nih.gov/pmc/articles/PMC6224788/

20. Coates J. Food and nutrition technical assistance [Internet]. USAIDS. 2006. Available from: https://www.unscn.org/web/archives_resources/files/Refman_40_FANTA_2006_Househo 1d_Food_170.pdf

21. Article T, Part IS, The OF, Contents TOF. Screening and brief intervention for unhealthy drug use: little or no e cacy. 2021;1-11. Available from: https://doi.org/10.3389/fpsyt.2014.00121

22. FANTA. Food and Nutrition Technical Assistance. 2015;(June). Available from: https://www.fantaproject.org/

23. World Medical Association. Declaration of Helsinki, Ethical Principles for Scientific Requirements and Research Protocols. Bull World Health Organ [Internet]. 2013;79(4):373. Available from: https://www.wma.net/policies-post/wma-declaration-of-helsinki-ethicalprinciples-for-medical-research-involving-human-subjects/

24. Gedle D, Gelaw B, Muluye D, Mesele M. Prevalence of malnutrition and its associated factors among adult people living with HIV / AIDS receiving anti-retroviral therapy at Butajira Hospital , southern Ethiopia. 2015;1-11. Available from: https://bmcnutr.biomedcentral.com/articles/10.1186/2055-0928-1-5

25. Alemayehu M, Garoma S, Gemede HF. Assessment of Adult Nutritional Status and Associated Factors Among ART Users in Nekemte Referral Hospital and Health Center, East Wollega Zone, Assessment of Adult Nutritional Status and Associated Factors Among ART Users in Nekemte Referral Hospital a. 2015;(April). Available from: https://www.researchgate.net/publication/277813640_Assessment_of_Adult_Nutritional_ Status_and_Associated_Factors_Among_ART_Users_in_Nekemte_Referral_Hospital_an d_Health_Center_East_Wollega_Zone_Ethiopia

26. Hailemariam S, Bune GT, Ayele HT. Malnutrition : Prevalence and its associated factors in People living with HIV / AIDS , in Dilla University Referral Hospital. BioMed Centeral [Internet]. 2013;1-11. Available from: https://archpublichealth.biomedcentral.com/articles/10.1186/0778-7367-71-13

27. Kabalimu TK, Sungwa E, Lwabukuna WC. Malnutrition and associated factors among adults starting on antiretroviral therapy at PASADA Hospital in Temeke District, Tanzania. 2018;20(2). Available from: doi: http://dx.doi.org/10.4314/thrb.v20i2.5\%0AMalnutrition

28. Benzekri NA, Sambou J, Diaw B, Sall EHI, Sall F, Niang A, et al. High prevalence of severe food insecurity and malnutrition among HIV-infected adults in Senegal, West Africa. PLoS One [Internet]. 2015;10(11):1-17. Available from: 
https://journals.plos.org/plosone/article?id=10.1371/journal.pone.0141819

29. Berhe N, Tegabu D, Alemayehu M. Effect of nutritional factors on adherence to antiretroviral therapy among HIV-infected adults: A case control study in Northern Ethiopia. BMC Infect Dis [Internet]. 2013;13(1). Available from: https://bmcinfectdis.biomedcentral.com/articles/10.1186/1471-2334-13-233

30. Palaniappan U, Starkey LJ, O'Loughlin J, Gray-Donald K. Fruit and vegetable consumption is lower and saturated fat intake is higher among Canadians reporting smoking. J Nutr [Internet]. 2001;131(7):1952-8. Available from: https://pubmed.ncbi.nlm.nih.gov/11435513/

31. Thapa R, Amatya A, Pahari DP, Bam K, Newman MS. Nutritional status and its association with quality of life among people living with HIV attending public anti-retroviral therapy sites of Kathmandu Valley, Nepal. AIDS Res Ther [Internet]. 2015;12(1):1-2. Available from: https://pubmed.ncbi.nlm.nih.gov/25937825/ 
Figures

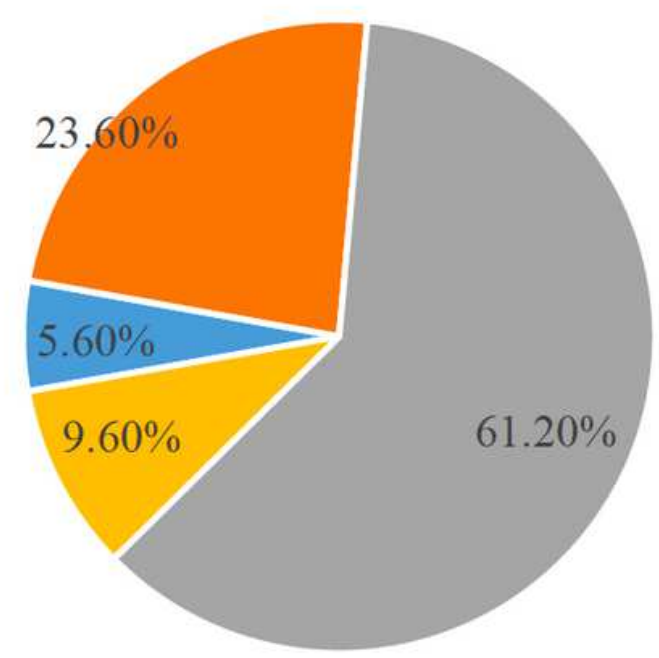

- Sever malnutrition " Moderate malnutrition " Normal " Over weight or obese

\section{Figure 1}

Nutritional status of HIV/AIDS patients on follow-up care in Bench Sheko zone public hospitals, Southwest Ethiopia, 2020 